\title{
Archaeological Survey of Areas Proposed for Modification in the Encino Park Development, Northern Bexar County, Texas
}

\author{
A. Joachim McGraw \\ Fred Valdez Jr. \\ Department of Anthropology, The University of Texas at Austin \\ Waynne Cox
}

Follow this and additional works at: https://scholarworks.sfasu.edu/ita

Part of the American Material Culture Commons, Archaeological Anthropology Commons, Environmental Studies Commons, Other American Studies Commons, Other Arts and Humanities Commons, Other History of Art, Architecture, and Archaeology Commons, and the United States History Commons

Tell us how this article helped you.

This Article is brought to you for free and open access by the Center for Regional Heritage Research at SFA ScholarWorks. It has been accepted for inclusion in Index of Texas Archaeology: Open Access Gray Literature from the Lone Star State by an authorized editor of SFA ScholarWorks. For more information, please contact cdsscholarworks@sfasu.edu. 


\section{Archaeological Survey of Areas Proposed for Modification in the Encino Park Development, Northern Bexar County, Texas}

\section{Creative Commons License}

\section{(c) (1) \&}

This work is licensed under a Creative Commons Attribution-NonCommercial 4.0 International License 
ARCHAEOLOGICAL SURVEY OF AREAS PROPOSED FOR MODIFICATION IN THE ENCINO PARK DEVELOPMENT, NORTHERN BEXAR COUNTY, TEXAS

A. Joachim McGraw, Fred Valdez, Jr. and Waynne Cox

Center for Archaeological Research The University of Texas at San Antonio Archaeological Survey Report, No. 39

1977

UTSA - Center for

Archaeolog .... Research 


\section{AN ARCHAEOLOGICAL SURVEY OF AREAS PROPOSED FOR MODIFICATION IN THE ENCINO PARK DEVELOPMENT, NORTHERN BEXAR COUNTY, TEXAS}

A. Joachim McGraw, Fred Valdez, Jr. and Waynne Cox

Center for Archaeological Research The University of Texas at San Antonio Archaeological Survey Report, No. 39 
List of Figures................. . . $i$. .

List of Tables .....................

Introduction . . . . . . . . . . . . . . 1

The Survey .................... . 1

Previous Archaeological Research ............ 2

Physical Environment ............... 3

Chronology of Prehistoric Habitation . . . . . . . . 7

Site Descriptions................ 8

The Artifacts . . . . . . . . . . . . . 23

Summary and Recommendations ............. 29

Acknowledgments . . . . . . . . . . . . . . 34

References Cited ............... 35 


\section{LIST OF FIGURES}

Figure

Page

1. General Views of Encino Park. .......... 4

2. Soil Map of Encino Park ............ 5

3. Plan of Encino Park Indicating Locations of Sites. . . . 9

4. Preforms and Projectile Points from Encino Park .... 24

5. Additional Lithic Artifacts from Encino Park. . . . 26

\section{LIST OF TABLES}

Table

Page

1. Distribution of Projectile Points and Selected

Artifacts ............. . 27

2. Sites Recommended for Further Research . . . . . . 31 


\section{INTRODUCTION}

During late April and May of 1977, individuals from the Center for Archaeological Research. The University of Texas at San Antonio (UTSA), conducted a preliminary archaeological survey and assessment of the proposed 2500-acre Encino Park Development in northern Bexar County. The work was conducted in two phases by two different teams working during the periods of Apri1 25May 4 and May 16-20, 1977, although both investigated portions of the East and West Elm Creek drainages and adjacent upland areas. The archaeological assessment was carried out under contract with the Denton Development Corporation.

The intent of the survey was to locate and assess archaeological sites in the Encino Park study area and to evaluate their significance before destruction or alteration occurred. Proposed developments will alter or modify major areas of the present physical topography near the EIm Creek drainages and will thus eventually disturb the local archaeological resources.

\section{THE SURVEY}

The investigation of the Encino Park area was based upon a systematic survey directed toward: (1) location of archaeological sites; (2) a preliminary assessment by surface examination of their content and importance; (3) the detailed recording of such information for future research; and (4) recommendations for any further investigations at the sites. The methodology involved in this survey generally followed the guidelines of Hester. Heizer and Graham's Field Methods in Archaeology (1975), and included these elements: (1) to use as much accuracy as possible in describing, analyzing, and evaluating identified sites; (2) to develop reasonable guidelines for further studies; and (3) to formulate conclusions relevant to cultural processes. In actual practice, the observation of material distributions such as lithic concentrations was of particular importance and was carefully noted not only to define site boundaries but to locate areas of special activity. Consideration was also given to the presence or absence of particular cultural materials as well as specific elevations and distances of sites from water sources (McGraw 1977). Emphasis of the investigation was directed at obtaining as complete a sample as possible of diagnostic artifacts from all areas of the development. Controlled surface collection was rejected in this initial assessment as too inefficient in both time and manpower.

All sites identified in the Encino Park Study have been recorded on standard site survey forms used by the Center for Archaeological Research, UTSA. Black and white $35 \mathrm{~mm}$ photographs and color slides were also taken of various sites. Additionally, all sites were plotted on U.S.G.S. topographic maps. Artifacts were collected at most sites and placed in plastic or paper bags which were labeled as to survey area, site number, date, type of collection and collector's name.

The survey of the proposed Encino Park Development was done in two phases, the first during Apri1 25-May 4, and the second during May 16-20. In the 
first phase, emphasis was placed on a careful inspection of the southern part of the development. It is this sector that is scheduled for initial construction activities. The area is south of the entry road into the project area and extends from the western fenceline to a branch of Elm Creek north of Yates Landing. In essence, the first phase of the survey was concerned with the lower elevations within the project area.

The second survey was concerned with upland elevations and slopes, primarily in the northern portion of Encino Park. This area of development was divided by the survey team into five sub-areas, one of which was surveyed each day. The boundaries of the areas were arbitrary, but usually followed some physical separation, e.g., a roadway or a fenceline.

All materials were collected and processed according to standard archaeological procedures and the assessments presented in this report are based upon an analysis of artifacts, photographs, survey forms and field notes.

\section{PREVIOUS ARCHAEOLOGICAL RESEARCH}

Over 400 archaeological sites have been recorded in Bexar County and this makes it one of the most studied counties in Texas. Until the present, most archaeological research in the region has been in the form of surveys, and little sustained research has taken place. A summary of earlier work has been publisted by Fawcett (1972; see also Woolford 1935); also contained in Fawcett's report is a bibliography of published and unpublished reports dealing with Bexar County archaeological research (see also Hester et al. 1974). Investigations within the last two years in portions of northern Bexar County and adjacent Comal County (in the vicnity of the Encino Park Development) which may have a direct relationship to this report include an archaeological survey of Friedrich Park (Smith and McDonald 1975), a brief description of the Menger collection, a series of various late Paleo-Indian and Archaic artifacts uncovered in northern Bexar County in the early 1960s (Chadderdon 1975), the Fort Sam Houston Project, testing at 41 BX 300, and Studies at Floodwater Retarding Structure No. 11 (for the Soil Conservation Service). Reports on the latter three projects are under preparation at the Center.

An actual synthesis of archaeological investigations in northern Bexar County is lacking. An analysis of prehistoric utilization of upland areas in this general region has been published by W. B. Fawcett, Jr. (1974) and although this is only a preliminary attempt at unraveling the complex mystery of aboriginal settlement patterns, lithic tool kits, and other cultural and environmental factors, Fawcett's basic assumptions may prove too generalized on which to base working models.

A high percentage of the archaeological sites reported in the county are from areas along or peripheral to the Salado Creek drainage (Elm Creek is a tributary of this system). Some of the important sites along Salado Creek include the St. Mary's Hal1 site (41 BX 229), the Granberg site (Schuetz 1966), the Granberg II site (Hester and Kohnitz 1975) and a series of sites on the Walker Ranch reported by Scurlock and Hudson (1973 and Hudson, Lynn and Scurlock 
(1974). These and other sites along Salado Creek and its related areas suggest intensive aboriginal activity during the prehistoric period (Hester et al. 1974).

\section{PHYSICAL ENVIRONMENT}

The environmental and physiographic conditions of this region are inordinately complex and this report will attempt to define only the most relevant elements.

The Encino Park Development is situated on the Balcones Fault Zone and lies on the edge of a broad transition area that separates the Edwards Plateau Escarpment from the lower elevations of the Gulf Coastal Plain. The entire development area overlies the recharge zone of the Edwards Aquifer and local topography is characteristic of the Texas hill country with many prominent elevations composed of eroding limestone formations and light soil cover (Fig. 1,a). Rock outcroppings here are geologically classified as part of the Edwards-Limestone Complex (Ked) in the lower Cretaceous Formations of the Mesozoic Era. The Edwards includes an upper portion 300-500 feet thick composed of fine- to coarse-grained materials and abundant chert, colored medium gray to grayish-brown. Permanent water sources are few but springs and intermittently running drainage systems are interspersed through the region.

Surface elevations in the locality range from ca. 930' at the stream beds and floodplains to $\mathrm{Ca}$. 1230' above mean sea level (msl) atop Classen Hill, the highest point in the 2500-acre area. Two streams, (East) Elm Waterhole Creek and West Elm Creek, drain the area southward and presently hold water only during run-off. However, the width of the stream channels and depth of eroded limestone in creek beds suggest that in the past the drainages may have been spring-fed during some portion of the year.

Soils (Fig. 2)

Soils in the study area generally consist of two soil associations, although this broad description does not reflect the possible complications caused by the local drainage system in the form of redeposition, alluvium, erosion, etc.

The dominant soil of the area is the Tarrant Association Rolling (TaC), comprising ca. $74 \%$ of the survey area. The soil has a low capacity to hold water but a high fertility ratio, with an adequate water supply. Thin and stony, the soil surface is characterized by a 5 to $15 \%$ slope and is composed of clayey and calcareous materials (Taylor et al. 1966:30).

A related soil type of the same association found in several higher elevations is classified as Tarrant Association, Hilly (TaD), differing from the former primarily by the increase in slope, 15 to $30 \%$. A notable feature of TaD is the rapid run-off due to steep slopes and exposed bedrock (Taylor et al. 1966).

The second soil association that was encountered in portions of the southern and eastern survey areas was identified as Crawford-Bexar Stoney Soil $\left(C_{B}\right)$, 


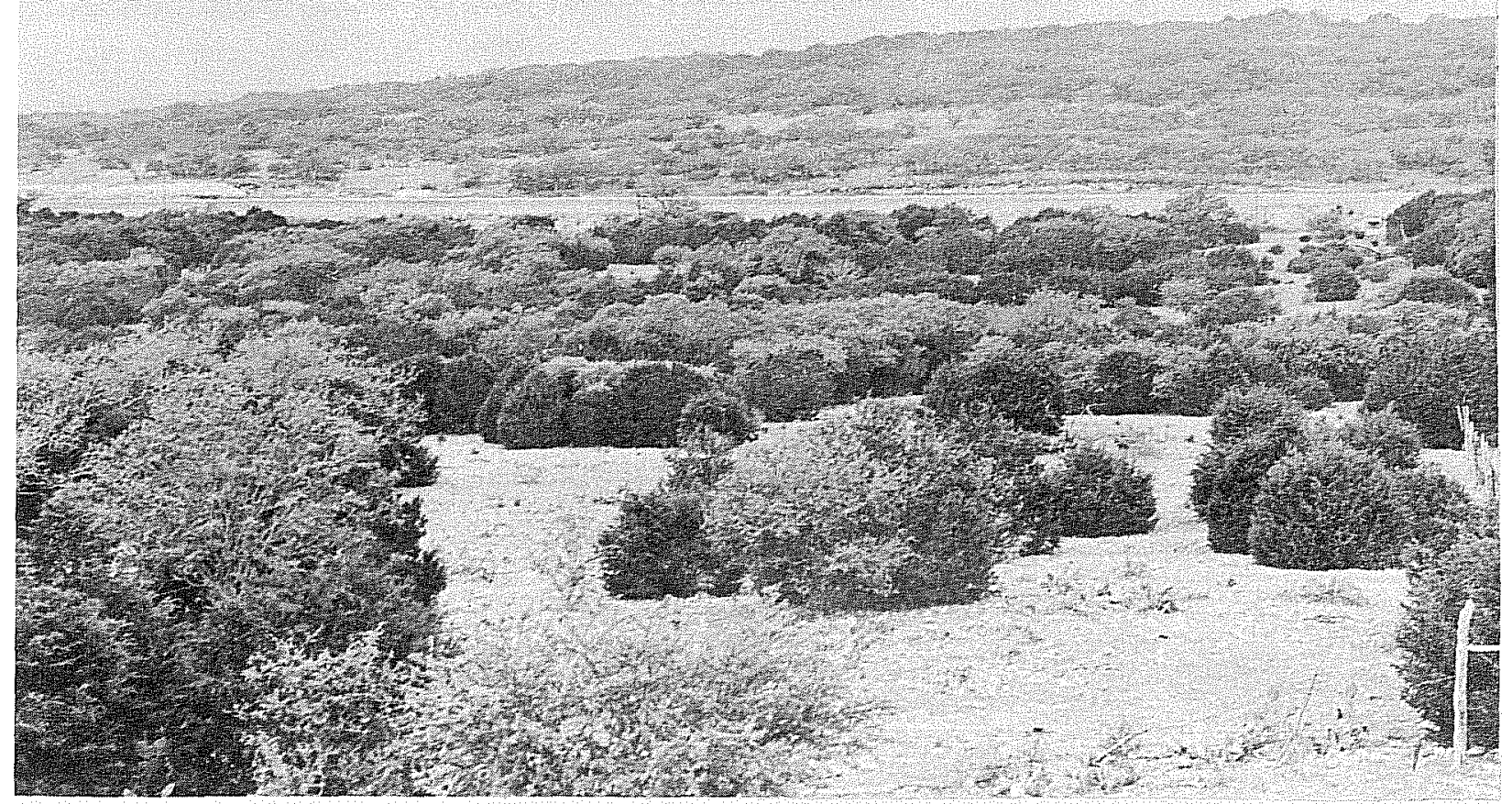

a

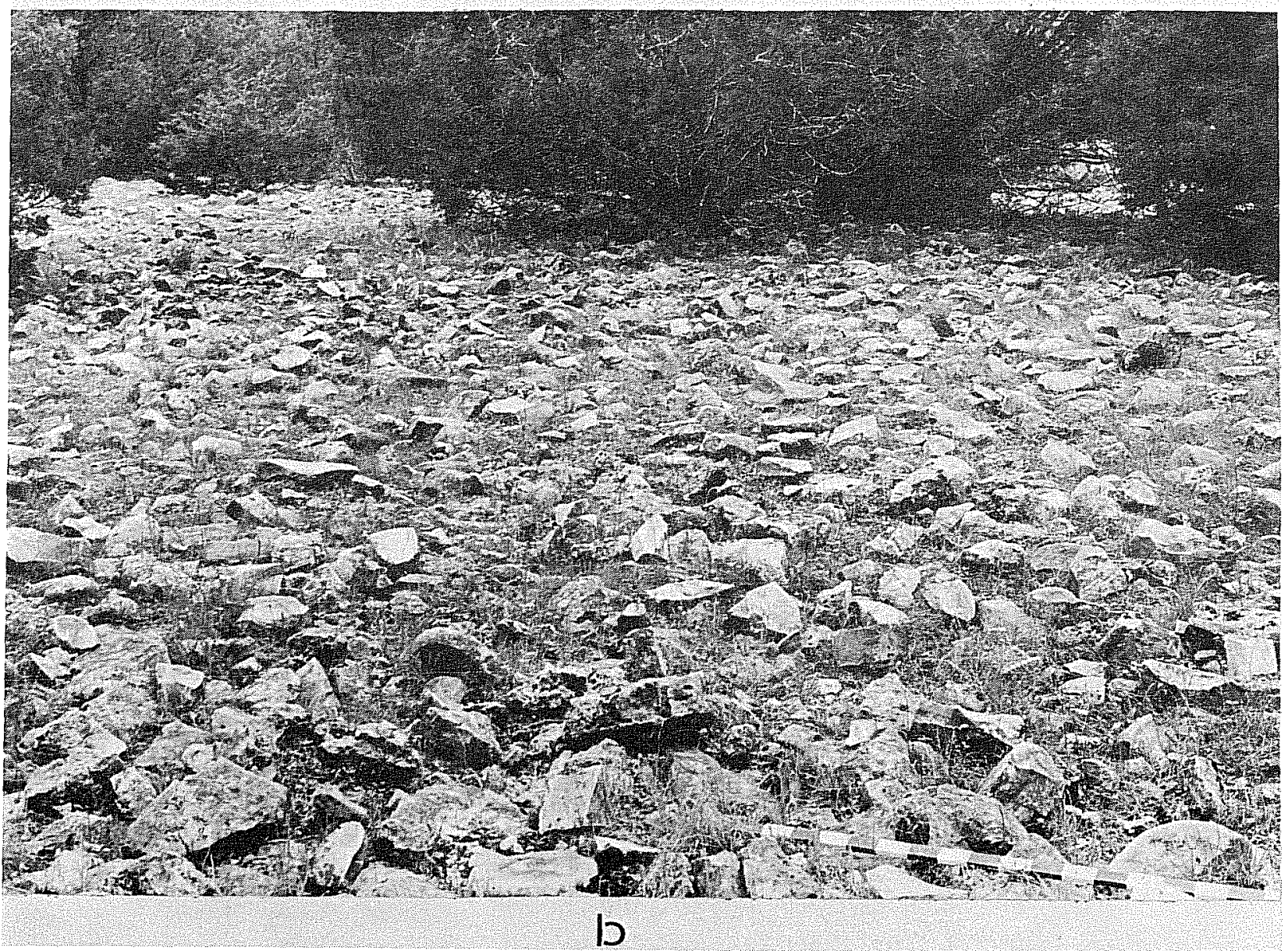

Figure 1. General Views of Encino Park. a, View of park looking west; b, view of site EP-32 (41 BX 121) looking north. 


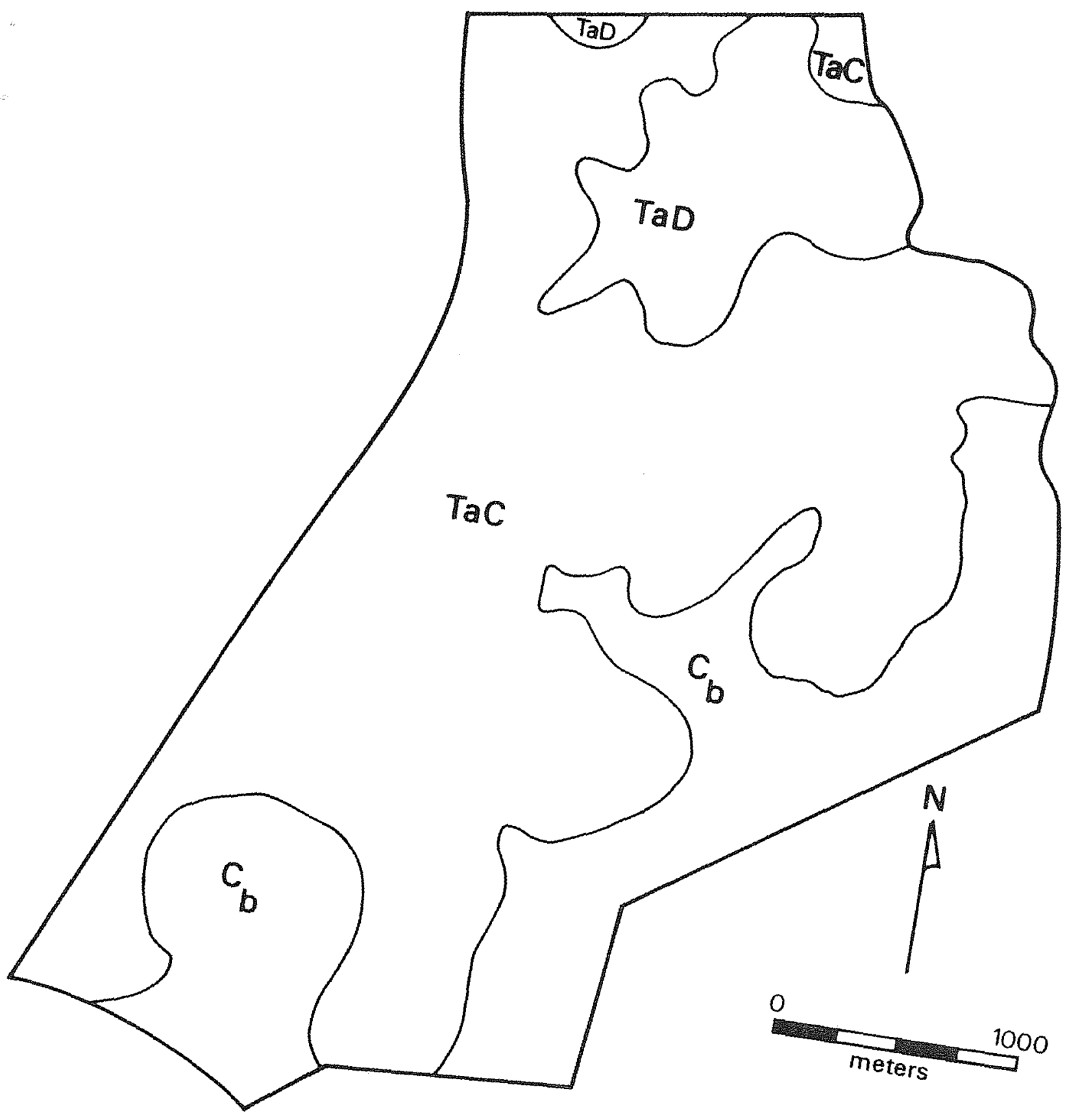

Figure 2. Sail Map of Encino Park. 
comprising ca. 18\% of the Encino Park Development. The soil is dark grayishbrown to reddish-brown and contains substantial portions of clay, chert and limestone materials (Taylor et al. 9966 ).

Climate

Climate of this area is generally sub-tropical with comparatively mild winters and hot summers. Record highs and lows, respectively, vary from $106^{\circ}$ to $0^{\circ} \mathrm{F}$, but the average daily maximum and minimum, respectively, are $79.2^{\circ}$ and $58.1^{\circ}$. Precipitation is distributed throughout the year and averages 27.89 inches (Taylor et al. 1966:120). Rain in the form of thunderstorms occurs in a 11 seasons except winter and this often causes serious flooding of local waterways and low-water areas. Northerly winds predominate during winter months and southeasterly Gulf winds prevail during the summer. The relative humidity norma $17 y$ ranges from $80 \%$ in the morning hours to $\mathrm{ca} .50 \%$ by late afternoon. The period from the last spring freeze to the first in fall averages 245 days (ibid.).

\section{Flora}

The location of this study area in a geologic transition zone and the general soil fertility combine to create a wide diversity of areal micro-ecosystems, most obvious in the variety of flora. In the past, the soil has been known to support a vast array of native grasses: little and feathery bluestem, sideoats, gramma, plains lore-grass, green sprangletop, Texas cup-grass, Indian grass, buffalo grass and others. During the survey, climax vegetation noted in soil zones $\mathrm{TaC}$ and $\mathrm{TaD}$ included cedar (Juniperus sp.), shin oak and scrub live oak (Quercus sp.), with an occasional Texas persimmon (Diospyros texenis) and mesquite (Prosopis juliflora). The uplands also support several species of cacti; most notably, prickly pear (Opuntia sp.), devil's head (Echinocatus texensis), yucca (yucca sp.), agarita (Berberis trifoliolata), and occasionally sotol (Dasylirion sp.).

In the deeper soils of the lower elevations, the frequency of cedar declines and live oak (2. virginianus) becomes dominant, with scrub brush increasing.

Fauna

A short list of contemporary fauna common to the study area is given below. It should be noted that this list reflects only current fauna and excludes bison, antelope, wolves and other animals present during parts of the Prehistoric and early Historic period.

Mamma 75

Coyote (Canis latrans)

Gray fox (Urocyon cinereoargenteus)

Striped skunk (Mephitis mephitis)

Mexican ground squirre1 (Spermophilus mexicanus)

Fox squirrel (Sciurus niger)

California jack rabbit (Lepus californicus)

Eastern cottontail (Sylvilagus floridanus) 
White-tailed deer (Odocoileus virginianua)

Raccoon (Procyon lotor)

Opossum (Didelphis virginiana)

Nine-banded armadi110 (Dasypus novemcinctus) (Davis 1974; Hudson, Lynn, and Scurlock 1974)

\section{Reptiles/Amphibians}

Earless lizard (Holbrookia texana)

Four-lined skink (Eumeces brevilineatus)

Texas garter snake (Thamnophis sirtalis)

Diamondback watersnake (Natrix rhombifera)

Western diamondback rattlesnake (Crotalus atrox)

Texas toad (Bufo speciosus)

Birds

Although subject to seasonal migration, common fowl include:

Common egret (Casmerodius albus)

Great blue heron (Ardea herodias)

Green heron (Butorides virescens)

Little blue heron (Florida caerulea)

Turkey vulture (Cathartes aura)

Red-tailed hawk (Buteo jamaicensis)

Carolina chickadee (Parus carolinensis)

Mockingbird (Mimus polyglottas)

Short-eared ow1 (Asio flammeus)

Cardinal (Cardinalis cardinalis)

Roadrunner (Geococcyx californianus)

Not noted in the survey but observed nearby, several miles to the southeast in isolated creeks and quiet streams, were several varieties of wild ducks, including mallards and wood ducks.

\section{CHRONOLOGY OF PREHISTORIC HABITATION}

The archaeology of the transition zone between the lower Gulf Coast elevations and the Edwards Plateau region is still poorly defined. While artifact evidence in the area suggests occupation dating to at least 9200 B.C., very little is known of the varied cultural complexes throughout this length of time. Four major time periods are represented by aboriginal sites in the vicinity of the Encino Park Development and are briefly defined as the PaleoIndian, the Archaic, Late Prehistoric (or Neo-American) and Historic.

The Paleo-Indian period (ca. 9200-6000 B.C.) is represented at site 41 BX 229 in northern Bexar County by the occurrence of fluted Folsom and Plainview projectile points. Although the Archaic period (ca. 6000 B.C.-A.D. 1000) is generally considered to follow the Paleo-Indian, there is increasing evidence, in south and central Texas, of a transitional phase following the end of the Paleo-Indian period and preceding the presently defined "Early Archaic." 
The data on this transition, tentatively labeled the "Pre-Archaic," come from a series of sites including Baker Cave, Stillhouse Hollow, La Jita, and others. Lithic traits include notched and triangular dart points, large, barbed points, and stemmed points termed Gower (Hester 1975).

The second major time period, the Archaic, suggests a long span of hunting and gathering lifeways. It is represented in the study area by stemmed and triangular dart points, lithic forms such as Clear Fork and Guadalupe tools, and large, thin bifaces. The Archaic is presently divided into three major units, Early, Middle, and Late, and most Archaic sites of all phases contain an abundance of chipped stone artifacts. The highest frequency of datable sites near the study area is linked to Middle and/or Late Archaic occupations (Hester et al. 1974).

A major problem through the periods generally, but especially significant during the Archaic, is the lack of a definitive chronology, which limits the understanding of various prehistoric cultures. Combined with an inconsistent typological system of artifact classification, the lack of a good chronology is a major stumbling block in the analys is of south and central Texas archaeology.

The third phase, the Late Prehistoric (Neo-American; ca. A.D. 1200+), was marked by the introduction of the bow and arrow which abruptiy modified archaeological assemblages. Smal1 arrow points of distinctive types, new 1 ithic forms, and occasional bone-tempered ceramics made their appearance after A.D. 1200.

The Historic period is represented by Historic Indian groups and early AngloEuropean activities. Intrusive Plains Indians such as the Lipan Apache and Comanche moved into the area in the 17 th and 18 th centuries, filling the void left by the "missionization" and cultural breakdown of native groups.

The variety of archaeological sites found in northern Bexar County, as identified by earlier work, includes occupation sites (campsites), burned rock mirnens, chert quarries, workshops, temporary campsites and rocksheiters. (Frar additional descriptions of Bexar County sites, see Fawcett 1972).

\section{SITE DESCRIPTIONS}

Site descriptions in this section maintain the format listed below, using the data recorded on standard site survey forms. The site designations follow a terrorary identification consisting of a two-letter combination ("EP" indicatirg Encino Park) and a number assigned to the individual site (Fig. 3). Site nurbers were arbitrarily given in order of discovery; consecutively numbered sites may, but do not necessarily, imply cultural relationships. In parentheses, following the temporary number, we have indicated the official state triromial designation. Site descriptions include the following standard intormation (cf. Nunley and Hester 1975): 
This page has been

redacted because it

contains restricted

information. 
Location: Indicates the site as viewed from a general geographic and environmental context and in respect to known geographic features: fencelines, roads, etc.

Elevation: Elevation above mean sea level (msl) as identified through U.S.G.S. topographic maps. Elevations are given in feet in order to correspond with project and U.S.G.S. maps.

Description: Brief, specific statements concerning the occupation evidence, its depth, extent, and condition.

Type of site: 0ccupational (campsite), quarry, workshop, temporary occupation, stream terrace, etc.; often may be identified as "multifunctional" if a variety of activities are thought to have occurred at the locality.

Environmental characteristics: A brief geographic and environmental description which may include information on local topography, vegetation, and soil.

Interpretation/Remarks: A preliminary analys is of the extent, importance, and condition of the site; this section will include recommendations for future investigation.

For a definition of unfamiliar terms sometimes used in the following sections, particularly those in site and artifact descriptions, the reader is referred to Fox and Hester (1976:13-14) for an excellent basic summary of commonly used archaeological terms relevant to the study.

EP-1 $(41$ BX 90)

Location: West ridge of drainage \#1. Starts at ca. 200 meters south of main road into survey area and extends ca. 500 meters southward. Southern edge is on ridge west of the large bend of the drainage near the southern boundary line of the developmental area.

Elevation: Maximum ca. 1020', minimum ca. 1000' above ms 1.

Description: 0blong quarry/campsite ca. 400 meters north-south and 225 meters east-west. Cores, flakes, quarry blanks, unifacial scrapers, bifacial scrapers, utilized flakes, and a possible bifacial knife were found scattered over the area.

Type of site: Multifunctional; quarry/campsite

Environmental characteristics: Site is located on ridge top west of drainage. Vegetation includes juniper, live oak, prickly pear, agarita, and mesquite. Soils was identified as reddish clay loam, very rocky, with limestone and chert.

Interpretation/Remarks: No further work is recommended. 


\section{$E P-2 \quad(41 \quad B X 91)$}

Location: Bounded on the west by San Pedro Avenue (U.S. Highway 281). North of the main ranch road. The northern boundary is along a drainage of West Elm Creek. The site extends east from the San Pedro line ca. 500 meters.

Elevation: Maximum 1030', minimum 990' above ms 1 .

Description: Rectanguloid collecting locality, temporary campsite, and possible quarry site. Dimensions are ca. 400 meters north-south and 375 meters east-west. Cores, flakes, retouched flakes, chunks, quarry blanks and heat-treated chert litter area.

Type of site: Multifunctiona 1 ; quarry, campsite, workshop.

Environmental characteristics: Site is located on the relatively flat portion of higher elevation sloping toward creek drainage. Vegetation includes juniper, live oak, prickly pear, and wild grasses. Soil was shallow over bedrock, black with many rock cobbles and some chert.

Interpretation/Remarks: Condition of site may be damaged; some erosion, clearing and bulldozing have taken place. No further work is considered necessary at this site.

\section{EP-3 (41 BX 92)}

Location: The southern boundary of the site is at the southern boundary of the park. The western boundary follows the east bank of a drainage and the eastern boundary is a branch of the main ranch road (the branch turns slowly south). The northern point of the site extends to a drainage branch of West Elm Creek.

Elevation: Maximum 1019', minimum 960' above ms1.

Description: Multifunctional site ca. 700 meters north-south and 500 meters east-west. Archaeological evidence includes cores, scrapers, flakes, quarry blanks, utilized flakes, and bifaces.

Type of site: Multifunctional; quarry, campsite, and lithic scatter.

Environmental characteristics: Site is located on the floodplain, relatively flat with a slight slope along the creek (branch) drainage. Vegetation includes juniper; live oak, prickly pear, persimmon, agarita, and wild grasses. Soils vary from stony, reddish clay to brown clay loam.

Interpretation/Remarks: Condition of site is slightly to heavily eroded. No further work is recommended.

EP-4 (41 BX 93)

Location: Ca. 175 meters southeast of site EP-3 and ca. 500 meters due south of entrance road (refer to Fig. 3). 
Elevation: Maximum 970', minimum 960' above ms 1 .

Description: Circular lithic scatter ca. 125 meters in diameter containing cores, flakes, retouched flakes, unifaces, and quarry blanks.

Type of Site: Lithic scatter.

Environmental characteristics: Site is located on a flat, limestone outcropping. Vegetation includes persimmon, mesquite, juniper, acacia, agarita, briar, prickly pear, live oak, and wild grasses. Soil was cherty clay loam, reddish in color.

Interpretation/Remarks: No further work is recommended.

EP-5 (41 BX 94)

Location: West bank of West Elm Creek, beginning 60 meters south of present main road and extending 300 meters south.

Elevation: Maximum 970', minimum 930' above ms1.

Description: An ovoid quarry/campsite ca. 300 meters north-south and 140 meters east-west. Archaeological evidence includes cores, primary and secondary flakes, bifacial scrapers, unifacial scrapers and quarry blanks.

Type of site: Quarry/workshop.

Environmental characteristics: The site is located on the second terrace of a stream, heaviest where the limestone layer is exposed. Vegetation includes oak, juniper, mesquite, prickly pear, and agarita. Soil was identified as a reddish clay loam with much 1 imestone and chert.

Interpretation/Remarks: No further work is recommended.

EP-6 $(41 \quad B X$ 95)

Location: On top of a small bluff above the floodplain of West Elm Creek, west of where drainage \#3 enters.

Elevation: Maximum $940^{\prime}$, minimum $920^{\prime}$ above ms 1

Description: The site is a circular lithic scatter ca. 40 meters north-south and 30 meters east-west. Evidence includes utilized flakes, cores, and burned rock. A possible hearth exists 30 meters northeast of site.

Type of site: Lithic scatter.

Environmental characteristics: Site is located on a bluff extending north along a secondary terrace of the drainage. Vegetation includes live oak, juniper, agarita, prickly pear, and white brush. Soils are shallow red, cherty, stony clay and limestone. 
Interpretation/Remarks: Present site condition can best be described as eroded and no further work is recommended.

\section{EP-7 (41 BX 96)}

Location: On east bank of West Elm Creek above where it turns south. Elevation: $930^{\prime}$ above ms 7 .

Description: An ovoid 1ithic scatter ca. 60 meters north-south and 30 meters east-west. Archaeological evidence includes flakes and utilized flakes.

Type of site: Lithic scatter.

Environmental characteristics: Site is located on a secondary terrace above a sloping bank of the drainage. Vegetation includes juniper, agarita, briar and live oak. Soils were identified as gravelly chert and red clay.

Interpretation/Remarks: Site is badly eroded and no further work is recommended.

\section{EP-8 $(41 \quad B X$ 97)}

Location: On ridge to west of West Elm Creek where Elm Creek crosses road to main house in park. 100 meters east of smal1 drainage that meets West Elm creek 75 meters south of road.

Elevation: $930^{\prime}$ above ms 1 .

Description: The site is an oval lithic scatter ca. 100 meters north-south and 75 meters east-west. Archaeological evidence includes a burned rock concentration, quarry blanks, cores, bifaces, modified and unmodified flakes.

Type of site: Lithic scatter, possible temporary campsite.

Environmental characteristics: Site is located on east slope of hill. Vegetation includes oak, juniper, agarita, cacti, mesquite and wild grasses. So il is a rocky, brown clay loam.

Interpretation/Remarks: Site condition is poor due to erosion; no further work is recommended.

EP-9 $(41$ BX 98$)$

Location: West bank of West Elm Creek on long, flat, clear terrace. Ca. 400 meters due west of hilltop 1056 in west central park area.

Elevation: Maximum 1000', minimum 980' ms 1 .

Description: An oval lithic scatter ca. 130 meters north-south and 50 meters east-west. Two projectile points were collected and flakes, scrapers and bifaces were noted. 
Type of site: Light lithic scatter.

Environmental characteristics: Site is located on a flat, wide terrace. Vegetation includes juniper, live oak, cacti, and persimmon. Soil is a rocky, black clay loam.

Interpretation/Remarks: Limited subsurface testing and mapping are recommended. EP-10 (41 BX 99)

Location: One-fourth mile east of San Pedro (on $1115^{\prime}$ contour) and ca. onefourth mile west of West Elm Creek on hilltop.

Elevation: Maximum 1115', minimum 1010' above ms 1 .

Description: A circular, large lithic scatter/campsite ca. 500 meters northsouth and 400 meters east-west. Area is scattered with large bifaces, scrapers, drills, dart points, flakes, and cores.

Type of site: Lithic scatter/campsite.

Environmental characteristics: Site is located on hillside and hilltop and concentrated on southern slopes. Vegetation includes live oak, persimmon, cacti, juniper, wild grasses, and agarita.

Interpretation/Remarks: Site condition is good with some erosion; recommendations include mapping, further testing of site where possible, and controlled surface collection.

EP-11 (41 BX 100)

Location: On east bank of West Elm Creek, east of highest peak in the center of the study area. Site is ca. 800 meters south of midway fence and 1600 meters north of exit road.

Elevation: Maximum 1000', minimum 980' above ms 1.

Description: Site is an oval lithic scatter/campsite ca. 300 meters northsouth and 175 meters east-west. Six dart points and preforms were collected; flakes, bifaces, and quarry blanks were also noted.

Type of site: Lithic scatter/campsite.

Environmental characteristics: Site is located on sloping terrace above creek with a possible deep soil deposit. Vegetation includes juniper, live oak, and agarita. Soil was a black, loamy clay with much gravel, cobbles, and chert.

Interpretation/Remarks: Site condition is partially eroded but limited testing, mapping, and controlled surface collection is recommended. 
EP-12 (41 BX 101)

Location: East of West Elm Creek beginning 15 meters west of creek. The site is located on a sloping terrace ca. 10 meters above creek and ca. 300 meters east of hilltop (1096' elevation).

Elevation: Maximum 1040', minimum 1020' above ms1.

Description: Site is an oblong lithic scatter ca. 30 meters north-south and 50 meters east-west. Flakes, cores, and chunks were found scattered throughout.

Type of site: Lithic scatter.

Environmental characteristics: Site is located on a sloping terrace adjacent to West Elm Creek. Vegetation includes juniper, live oak, prickly pear, wild grasses, and agarita. Soil is thinly scattered black, clayey loam over limes tone outcroppings.

Interpretation/Remarks: Site condition is poor and no further work is recommended.

EP-13 (41 BX 102)

Location: On the east bank of West Elm Creek. It extends ca. 20 meters west of the creek along the bank of a flat terrace.

Elevation: ca. 1040' above ms 1

Description: An ovoid lithic scatter that covers an area ca. 50 meters northsouth and 20 meters east-west along the flat terrace of the creek bank. Recovered materials include bifaces, an unidentified projectile point, biface fragments, utilized flakes and Tithic debris.

Type of site: Lithic scatter, possible occupation.

Environmental characteristics: Site is located on flat creek terrace. Soil is primarily clayey loam over rocky limestone; vegetation includes juniper, live oak, cacti and wild grasses.

Interpretation/Remarks: No further work is necessary.

EP-14 (41 BX 103)

Location: Ca. 150 meters north of EP-13 on a sloping terrace. The site covers the east bank of West Elm Creek, ca. 300 meters north-northeast of a hilltop location identified on a 1:24,000 topographic map as having an elevation of $1056^{\prime}$.

Elevation: Maximum 1050', minimum 1040' above ms 1.

Description: A roughly circular lithic scatter extending ca. 75 meters northsouth along the length of a creek terrace. Erosion has badly damaged the site. Materials recovered include an unidentified biface, utilized flakes, and an assortment of lithic debris. 
Type of site: Lithic scatter, possible light occupation.

Environmental characteristics: Soil consists of a light covering of black loam over limestone outcroppings. Juniper is the predominant vegetation.

Interpretation/Remarks: No further work is recommended due to the poor condition of the site.

EP-15 (41 BX 104)

Location: Site is on hilltop ca. 100 meters outh of windmill in the northwest section of the Encino Park Development.

Elevation: Maximum 1020', minimum 980' above ms 1.

Description: A circular lithic scatter ca. 75 meters in diameter. Recovered materials include quarry blanks, utilized flakes and lithic debris.

Type of site: Lithic scatter.

Environmental characteristics: Site is located atop a flat hill with steep slopes. Extensive chert cobbles outcrop along the length of the hill. Vegetation includes juniper, live oak, persimmon, cacti and wild grasses.

Interpretation/Remarks: No further work is recommended.

EP-16 $(41 \quad B \times 105)$

Location: Ca. 100 meters north of the windmi11 noted in EP-15.

Elevation: Maximum 1050', minimum 1030' above ms 1 .

Description: A light lithic scatter over a circular area, ca. 50 meters in diameter. Erosion has critically damaged site.

Type of site: Lithic scatter.

Environmental characteristics: Site is located on the north slope of a small saddle toward the east drainage. So il was identified as black loam over limestone outcroppings. Juniper, live oak, persimmon, cacti and wild grasses predominate.

Interpretation/Remarks: No further work is recommended.

EP-17 (41 BX 106)

Location: A hilltop site just north of the hilltop elevation 1152' (as identified on 1:24,000 topographic map). Site area extends along and east of the slope.

Elevation: Maximum 1050', minimum 1030' above msl. 
Description: A circular lithic scatter, ca. 75 meters in diameter. A possible midden $10 \times 15$ meters was identified in the center of the site. Waterials recovered include an unidentified projectile point, large bifaces, various scrapers, cores, and a scattering of flakes.

Iype of site: Occupation, workshop.

Environmental characteristics: Site is located on hilltop and slopes. Juniper, Tive oak, cacti, and persimmon are the dominant vegetation.

Interpretation/Remarks: Limited testing and mapping to determine potential of midden at site.

EP-18 (41 BX 107)

Location: On the west sloping ridge of Classen Hill near the highest point in the northwestern corner of Encino Park and just south of the northern boundary line.

Elevation: Maximum 1240', minimum 1120' above ms 1 .

Description: An ovoid lithic scatter and quarry site ca. 300 meters northsouth and 250 meters east-west. Materials recovered include large bifaces, scrapers, quarry blanks, cores, and flakes.

Type of site: Quarry, workshop.

Environmental characteristics: Soil is stony, black loam. Vegetation includes live oak and groves of persimmons with large clearings.

Interpretation/Remarks: Further investigation in the form of 1 imited testing (and mapping) where soil conditions permit.

EP-19 (41 BX 108)

Location: Near the northern fenceline at the head of a small drainage ca. 0.5 kilometer from the northwestern fence boundary.

Elevation: Maximum 1220', minimum 1180' above ms 1 .

Description: A quarry site ca. $40 \times 40$ meters. Materials recovered include quarry.blanks and primary flakes.

Type of site: Quarry.

Environmental characteristics: Site is located at the head of a small drainage. Light soll covers limestone outcroppings. Vegetation includes juniper, live oak, prickly pear, agarita and persimmon.

Interpretation/Remarks: No further work is recommended. 
$E P-20(41 \quad B \times 109)$

Location: On the east slope near the top of Classen Hill, ca. 150 meters south of the northern fenceline and ca. 600 meters from the west fenceline in a large, rocky clearing.

Elevation: Maximum 2030', minimum 2000' above ms1.

Description: A roughly circular lithic scatter ca. 60 meters in diameter. Lithic debris predominates and no diagnostic artifacts were recovered.

Type of site: Workshop.

Environmental characteristics: Site is located in a large rocky clearing. Soil is a black, stony loam surrounded by juniper.

Interpretation/Remarks: No further work.

$E P-21 \quad(41 \quad B \times 110)$

Location: Along the hilltop and slopes of elevation identified as $1173^{\prime}$ on 1:24,000 topographic map in northeastern area of Encino Park.

Elevation: Maximum 1173', minimum 990' above ms 1.

Description: An irregularly shaped area ca. 350 meters north-south and 500 meters east-west. A large lithic scatter suggests this was once an extensive activity area. Recovered materials include biface fragments, cores, unifacial tools and an assortment of flakes.

Type of site: Quarry/workshop.

Environmental characteristics: The site is located on the highest portions of the elevation. Predominant vegetation includes juniper, live oak, persimmon, agarita and cacti.

Interpretation/Remarks: Although heavily collected during its former capacity as a Boy Scout camp area, the nature of the site and recovered materials warrant controlled surface collections, mapping and limited testing.

EP-22 (41 BX 111)

Location: On both sides of ranch road leading from the ranch house as it curves toward the east. The site is bounded on the east by the survey boundary line and is ca. 50 meters north of the ranch complex.

Elevation: Maximum 995', minimum 975' above ms 1.

Description: An eroded lithic scatter in a rough semi-circular pattern, ca. 750 meters north-south and 75 meters east-west. Materials include cores, burned rock.

Type of site: Workshop/occupation. 
Environmental characteristics: Soil is identified as brown, clayey loam; vegetation includes juniper, live oak, mesquite, agarita, yucca and wild grasses.

Interpretation/Remarks: No further work.

$E P-23(41 \quad B X 112)$

Location: Both sides of a deer fence southwest of the confluence of East Elm Creek and a (dry) tributary. Site can be identified on a 1:24,000 topographic map as the hilltop and slopes between two larger hills with marked elevations of $1063^{\prime}$ and $1056^{\prime}$ above $\mathrm{ms}$.

Elevation: Maximum 1050', minimum 1020' above ms 7.

Description: An irregular lithic scatter ca. 325 meters north-south and 625 meters east-west. Materials collected include large biface fragments, preforms, cores and other lithic debris.

Type of site: Workshop/occupation.

Environmental characteristics: Soil is identified as Tarrant-Brackett; juniper as the predominant vegetation. The site is located in an upland area with no present water sources nearby.

Interpretation/Remarks: No further work.

EP-24 (41 BX 113)

Location: On the southeast slope of Classen Hill, near the survey boundary.

Elevation: Maximum 1140', minimum 1100' above ms 1 .

Description: The site forms a sloping saddle between hills. Lithic scatter consisting of bifaces, blanks, cores and scrapers is found on surface. The site extends $350 \mathrm{~m} \times 325 \mathrm{~m}$ and is ovoid in shape.

Type of site: Lithic scatter.

Environmental characteristics: Soil is very thin, black clay loam over limestone. Vegetation consists of live oak, juniper, agarita, cacti, mesquite, persimmon and small disperse grasses.

Interpretation/Remarks: No further work is recommended.

EP-25 (41 $B X \quad 114)$

Location: Site is on a knoll south-southwest of hi1l elevation 1175'.

Elevation: Maximum 1130', minimum 1100' above ms 1. 
Description: The site is roughly circular, approximately $250 \times 250 \mathrm{~m}$. Lithic evidence consists of flakes, bifaces, cores and blanks.

Type of site: Lithic scatter.

Environmental characteristics: Soil is thin, black clay over. 1 imestone. Vegetation consists of juniper, cacti, agarita, live oak and short grasses.

Interpretation/Remarks: No further work is required.

$E P-26 \quad(41 B X \quad 115)$

Location: The site is on the hill with $1104^{\prime}$ contour msl.

Elevation: Maximum 1104', minimum 1100' above ms 1.

Description: The site is circular and is $250 \mathrm{~m} \times 250 \mathrm{~m}$. Lithic scatter is comprised of bifaces and flakes.

Type of site: Lithic scatter.

Environmental characteristics: Soil is a black, clay loam over limestone. Vegetation is basically cacti, juniper, live oak, agarita and short grasses.

Interpretation/Remarks: No further work is required.

EP-27 (41 BX 116)

Location: On the south slope of hill 1104' msl contour and extends to East E7m Creek.

Elevation: Maximum 1140', minimum 1000' above ms 1 .

Description: The site takes on an oval shape covering $250 \mathrm{~m} \times 250 \mathrm{~m}$. Lithic scatter consisting of flakes, blanks, cores and bifaces is evident at the site.

Type of site: Lithic scatter.

Environmental characteristics: Soil is a black clay loam over limestone. Vegetation includes juniper, live oak, agarita, cacti and grasses.

Interpretation/Remarks: No further work is required. EP-28 (41 BX 117)

Location: On top of the hill with the 1094' msl contour on the northeast side near Bulverde Road.

Elevation: Maximum 1094', minimum 1050' above ms 1. 
Description: The site is oval to almost round. The dimensions are approximately $250 \mathrm{~m} \times 250 \mathrm{~m}$. The lithic scatter site is characterized by preforms, bifaces, scrapers, cores and flakes.

Type of site: Lithic scatter.

Environmental characteristics: Shallow, black clay loam over limestone describes the soil. Vegetation is represented by juniper, live oak, agarita, cacti, and grasses.

Interpretation/Remarks: No further work is required.

EP-29 (41 BX 118)

Location: One-fourth mile west of Bulverde Road (on 1094' contour) and three-fourths mile northeast of East Elm Creek.

Elevation: Maximum 1094', minimum 1060' above ms 1.

Description: The site is oblong, measuring $175 \mathrm{~m} \times 250 \mathrm{~m}$. The 1 ithic debris is composed of large bifaces, scrapers, cores, preforms and flakes.

Type of site: Lithic scatter, campsite and workshop.

Environmental characteristics: Shallow, black clay loam over limestone is the soil at this site. Large 1 imestone outcrops with chert in the limestone are located within the site boundaries. Vegetation includes live oak, persimmon, agarita, juniper, cacti and short grasses.

Interpretation/Remarks: Controlled surface collections and mapping are recommended.

EP-30 (41 BX 119)

Location: The site is on the southwest slope of hill 1094' elevation, toward the bend of East Elm Creek.

Elevation: Maximum 1100', minimum 1050' above ms 1 .

Description: The site has an almost rectangular shape with dimensions $650 \mathrm{~m} x$ $250 \mathrm{~m}$. Bifaces, cores, scrapers, and flakes form the 1 ithic scatter of the site.

Type of site: Lithic scatter.

Environmental characteristics: Characteristic of the soils in the general area, this site also has black clay loam over limestone. The vegetation includes juniper, Tive oak, agarita, cacti and grasses.

Interpretation/Remarks: No further work is required. 
EP-31 (41 BX 120)

Location: Northeast of East Elm Creek, $250 \mathrm{~m}$ north of the property 7 ine.

Elevation: Maximum 1000', minimum $30^{\prime}$ above ms 7 .

Description: The site is an ovoid lithic scatter extending $255 \mathrm{~m} \times 250 \mathrm{~m}$. Bifaces, cores and flakes characterize the site.

Type of site: Lithic scatter.

Environmental characteristics: The soil is a red-brown clay loam over limestone. Juniper, live oak, agarita, cacti and grasses characterize the vegetation.

Interpretation/Remarks: No further work required.

$E P-32 \quad(41 \quad B X 121)$

Location: On the west boundary 1 ine $1250 \mathrm{~m}$ south of the northern boundary Tine.

Elevation: Maximum 1096', minimum 1060' above ms 1.

Description: The site is circular with dimensions of $130 \mathrm{~m} \times 130 \mathrm{~m}$. Most material is of quarrying activity. Large crude bifaces, cores, large flakes (cortex) and chert outcropping (Fig. 1,b).

Type of site: Quarry.

Environmental characteristics: Soil is a thin, black clay loam over limestone with many chert outcrops (in the limestone). Vegetation represented includes juniper, scrub live oak, cacti and grasses.

Interpretation/Remarks: No further work is required.

$E P-33(41 \quad B X 122)$

Location: This site is $750 \mathrm{~m}$ southwest of site EP-32.

Elevation: Maximum 1090', minimum 1060' above ms1.

Description: The site is a quarry $(250 \mathrm{~m} \times 125 \mathrm{~m})$. Large crude bifaces, cores, large flakes and extensive chert outcroppings characterize the site.

Type of site: Quarry.

Environmental characteristics: Soil is very thin, black clay loam over limestone. Present vegetation at the site consist of juniper, live oak, mesquite, cacti and grasses. 
Interpretation/Remarks: No further work is required.

EP-34 (41 BX 123)

Location: The site is in the northeast section of the survey, $125 \mathrm{~m}$ from the north boundary and $125 \mathrm{~m}$ from the east boundary.

Elevation: Maximum 1150', minimum 990' above msl.

Description: An oval quarry area measuring $250 \mathrm{~m} \times 250 \mathrm{~m}$. The site is on a hillside slope and yielded bifaces, cores, large and small flakes.

Type of site: Quarry.

Environmental characteristics: Thin, black clay loam over outcropping limestone characterizes the soil. Vegetation is represented by juniper, live oak, agarita, cacti and grasses.

Interpretation/Remarks: No further work is required.

\section{THE ARTIFACTS}

Artifacts from the Encino Park Development were collected from the surface on the basis of diagnostic potential and are representative of types of materials occurring on the surface of the sites. Archaeological evidence was limited to lithic materials and in most instances was separated into morphological categories, e.g., cores, projectile points, bifaces, utilized flakes, etc. Following the general guidelines presented in Hudson, Lynn and Scurlock (1974), a short description of these is presented below.

Projectile Points (Fig. 4)

Twenty-three complete or fragmentary projectile points were recovered during the survey, most comprising different descriptive types. No other form than dart points was found and some of the recognized types described in the Handbook of Texas Archeology (Suhm and Jelks 1962) include Martindale, Darl, Marshall, Gower, Pedernales, Nolan and Travis, with the last two occurring most frequently. A possible Tortugas point was also collected.

Dart points fell into two general categories which were identified on the basis of obvious distinctive characteristics. Group 1 includes the dart points called Nolan, Travis, Tortugas, and Gower. Group 2 includes Pedernales and Martindale. Al1 identified points are illustrated. 




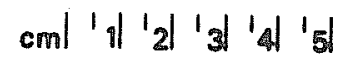

Figure 4. Preforms and Projectile Points from Encino Park. a, Darl; b-d, Gower; e, Nolan; $f$, Martindale; $g$, Marshall; $h$, possible Tortugas; $i$, preform; $j$, unidentified; $k$, Gower; 1 , preform; $m$, Travis; $n-0$, Pedernales; $p$, unidentified; $q$, preform; $r$, unidentified; $s$, preform; $t-w$, Thavis. 
Group 1:

№. of specimens: 11

Provenience: EP-1, EP-9, EP-11, EP-13, EP-17, EP-22

Descriptions: These specimens are characterized by large, thick, triangular bodies with straight to convex edges. The stems are generally rectangular with slightly expanding to slightly contracting edges. A notch or side indentation usually occurs in the base. Shoulders are fairly pronounced and sometimes barbed. The stem comprises $\mathrm{ca}$. one-third of the total Tength.

Group 2:

No. of specimens: 5

Provenience: EP-9, EP-11, EP-17, EP-22

Descriptions: These points are characterized by stems which were formed by removing a notch from either the base or the side. The stem usually constituted ca. one-fourth of the total length of the point. The bodies range from broad, triangular ones with convex edges to narrow, triangular ones with straight to slightly convex edges. Shoulders of Group 2 points are weak to fairly prominent, sometimes forming a barb which is as wide as the base (Hudson, Lynn and Scurlock 1974).

Miscellaneous Projectile Point Fragments, Bifaces and Flakes (Figs. 4 and 5)

Eight projectile point fragments were also discovered during the survey and some examples are shown in Fig. 4.

Numerous large bifaces of varying sizes, shapes and weights were both observed and collected; this category dominates the lithic collection. Specimens include those that exhibit bifacial thinning with marginal retouch and those that are crude and thick with no marginal retouch (Fig. 5).

Trimmed and utilized flakes were also noted at several sites in the Encino Park survey and their distribution is identified in Table 1. A large flake from $E P-28$ is shown in Fig. $5, a$. 

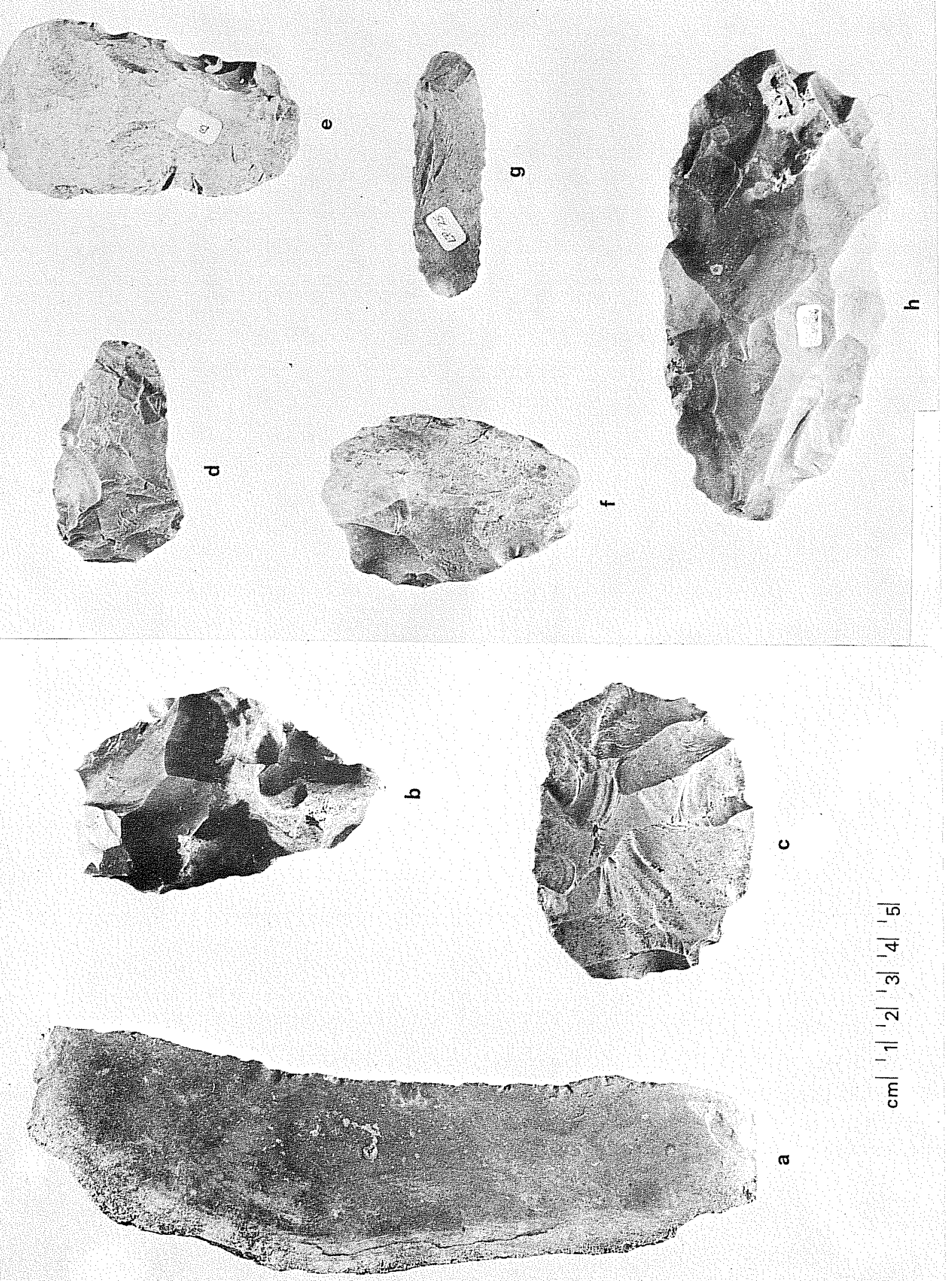

0

की
ल
ल
हु

ธ

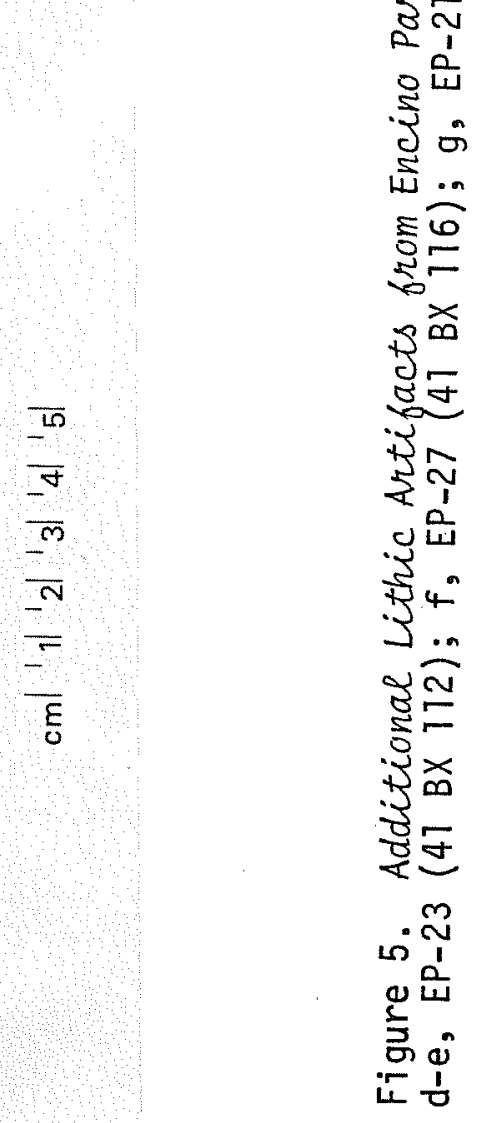


TABLE 1

DISTRIBUTION OF PROJECTILE POINTS AND SELECTED ARTIFACTS

\begin{tabular}{|c|c|c|c|c|}
\hline Site & Type & $\begin{array}{l}\text { Total number of } \\
\text { projectile points } \\
\text { and/or small bifaces }\end{array}$ & Identification & $\begin{array}{l}\text { Large bifaces } \\
\text { (larger than } 7 \\
\mathrm{~cm} \text { in length) }\end{array}$ \\
\hline$E P-1$ & $Q / 0$ & 1 biface & Tortugas (?) & \\
\hline$E P-2$ & WS/O & 5 bifaces & unidentified & 3 \\
\hline$E P-3$ & $Q / 0$ & 1 biface & $"$ & \\
\hline$E P-4$ & Q/WS & no artifacts collected & & \\
\hline$E P-5$ & Q/WS & $" \quad "$ & & \\
\hline EP-6 & WS & $1 " 1$ & & \\
\hline$E P-7$ & WS & 11 & & \\
\hline$E P-8$ & WS/0 (?) & $" 1$ & & \\
\hline EP-9 & WS/0 (?) & 3 bifaces & $\begin{array}{l}\text { Nolan, Marshall } \\
\text { and } 1 \text { unidentified }\end{array}$ & \\
\hline$E P-10$ & WS/0 & & & 6 \\
\hline$E P-11$ & WS $/ 0$ & 6 bifaces & $\begin{array}{l}\text { Pedernales, Travis, } \\
\text { Martindale }\end{array}$ & \\
\hline$E P-12$ & WS & no collection made & & \\
\hline EP-13 & WS & 1 biface & possible Gower & \\
\hline EP-14 & WS & 1 biface & unidentified & \\
\hline$E P-15$ & WS & no collection made & & \\
\hline$E P-16$ & WS & " " " & & \\
\hline EP-17 & WS/0 (?) & 4 bifaces & $\begin{array}{l}\text { includes Travis, } \\
\text { Dare }\end{array}$ & \\
\hline$E P-18$ & Q/WS & no collection & & \\
\hline EP-19 & Q & $" 1 "$ & & \\
\hline$E P-20$ & WS & " $\quad "$ & & \\
\hline$E P-21$ & Q/WS & $\begin{array}{l}1 \text { biface } \\
\text { fragment }\end{array}$ & unidentified & 12 \\
\hline$E P-22$ & WS $/ 0$ & $\begin{array}{l}18 \text { various } \\
\text { bifaces }\end{array}$ & $\begin{array}{l}\text { Pedernales, Gower } \\
\text { and preforms }\end{array}$ & 15 \\
\hline$E P-23$ & WS $/ 0$ & 3 & unidentified & \\
\hline$E P-24$ & WS & & & 8 \\
\hline$E P-25$ & & & & 5 \\
\hline$E P-26$ & & no collection made & & \\
\hline
\end{tabular}


Table 1 (continued)

\begin{tabular}{|c|c|c|c|c|}
\hline Site & Type & $\begin{array}{l}\text { Total number of } \\
\text { projectile points } \\
\text { and/or small bifaces }\end{array}$ & Identification & $\begin{array}{l}\text { Large bifaces } \\
\text { (larger than } 7 \\
\mathrm{~cm} \text { in length) }\end{array}$ \\
\hline$E P-27$ & WS & 2 bifaces & unidentified & 9 \\
\hline$E P-28$ & WS & & & 9 \\
\hline$E P-29$ & WS/0 & $\begin{array}{l}\text { utilized flakes } \\
\text { and preforms }\end{array}$ & & 20 \\
\hline$E P-30$ & WS & & & $\begin{array}{l}8 \text { and one } 21 \mathrm{~cm} \\
\text { triangular biface }\end{array}$ \\
\hline$E P-31$ & WS & $\begin{array}{l}\text { (utilized flakes } \\
\text { only) }\end{array}$ & & 12 \\
\hline$E P-32$ & $Q-1$ & no collection made & & \\
\hline$E P-33$ & $Q-2$ & $"$ & & \\
\hline$E P-34$ & Q-3 & no collection made & & \\
\hline
\end{tabular}

SYMBOLS:

$$
\begin{aligned}
& 0=\text { Occupation } \\
& \text { WS }=\text { Workshop/Lithic Scatter } \\
& Q=\text { Quarry }
\end{aligned}
$$


SUMMARY AND RECOMMENDATIONS

Summary

Since this is an assessment study, we will not attempt to present a detailed synthesis of Bexar County archaeology as it relates to the Encino Park area. This section will instead briefly describe the major aspects of the archaeology of the study area as seen in the context of the Northern Bexar County prehistoric record.

In the past, archaeological interest within the general area has fallen into two main studies: settlement patterns and lithic studies. Hester (1975) deals with the latter by describing lithic industries of the region. A further discussion of these processes from the standpoint of Encino Park would be impractical due to: (1) the orientation of the field survey toward only one element of lithic processes (diagnostic, finished artifacts); and (2) time limitations. However, general and preliminary observations can be made from the viewpoint of prehistoric settlement patterns in and near the study area. Hester (1976) emphasizes several characteristics of Archaic occupations in south Texas which are reflected in Encino Park: (1) the heterogeneity of aboriginal settlement patterns from one stream drainage to another (which may be due to temporal differences but in the main may reflect localized adaptational patterns; (2) a prehistoric emphasis to position sites in ecotone situations with access to several micro-environments; (3) aboriginal intrasite planning; and (4) functional differences of sites.

While a cursory inspection of archaeological evidence from Encino Park suggests al1 these elements are salient features of local aboriginal settlement patterns, unknown factors, combined with a lack of information, may unfortunately complicate and seriously modify any overall observations. Although various sites reflect distinctive aboriginal activities in the study area, the predominance of lithic workshop sites and the scarcity of permanent occupation sites in an area of over 2500 acres suggest unrecognized prehistoric influences, cultural and environmental, which affected both frequencies and distributions of prehistoric sites.

Whatever the causes, the recognition of functional differentiation is a key factor in understanding the archaeology of Encino Park and prehistoric behavior in north Bexar County. For the purposes of this report, the term "preferred quarry/workshop zones" will be used to identify the frequencies and distributions of a predominant type of activity throughout much of the area of Encino Park. For a clearer understanding of these areas to prehistoric lifeways, further studies of the archaeological character in the development not oniy must be directed toward site specificity but, perhaps more important, must analyze overall areal inter-relationships.

The archaeology of Encino Park can broadly be described as a locality in an ecological transition zone inhabited in the past primarily by various peoples of the Early to Late Archaic periods. Extensive artifactual evidence throughout the study area suggests much of the region was once used as quarry and workshop locations. The lack of sustained prehistoric occupation in the development as a whole, however, is curiously contrasted to the evident intensive activities involved in the 7 ithic reduction processes. 
As a phenomenon, past studies suggest these particular aboriginal characteristics are also common in nearby areas. A survey of the Salado Creek Watershed (Hester et al. 1974) investigated locations south of and adjacent to Encino Park. Floodwater Retarding Structure \#11 along Elm Creek reflects a continuation of activity patterns and ecosystems; however, the extent and frequency of sites found in this earlier study imply less concentrated activity. An important feature noted in the Salado Creek survey and not obvious in Encino Park was the common occurrence of sites on stream terraces. Preliminary investigations of Encino Park suggest site locations in general emphasize higher elevations rather than proximity to a water source.

Other similarities of nearby investigated areas of northern Bexar County (Hudson, Lynn and Scurlock 1974; Hester, Bass and Kerly 1975) include:

(1) extensive lithic scatter (more than 300 meters in length) and much lithic debris and evidences of workshop activity;

(2) a high frequency (in relative terms) of large, thin, and crude bifaces; and

(3) sparse archaeological remains of other types of activities.

Obvious differences noted between Encino Park and related areas can very general ty be summarized as:

(1) a higher frequency of smaller workshop/quarry sites in nearby areas;

2) a scarcity of cores in site areas;

(3) a higher incidence of continuing modifications of 1 ithic materials (not noted during the Encino Park survey); and

(4) the common occurrence of burned rock middens (not noted in the Encino Park survey).

Recommendations

Sites recommended for further research are discussed here.

The Encino Park Development is characterized by a predominance of Pre-Archaic to Early Archaic activities as reflected in the frequency and variety of projectile points surface collected. Much of the area has been used as large, quarrying/workshop localities during these time periods, and perhaps later (although no diagnostic evidence supports this latter assumption). The intensity of lithic reduction activities is in stark contrast to the relatively light evidence of intensive occupation, although the area appears to have had adequate natural resources to attract (and sustain) prehistoric population.

After a detailed analysis of survey reports, field notes, and collected or observed artifacts, our recommendations for further work consist of further testing, controlled surface collecting and mapping at the seven sites listed in Table 2. 
TABLE 2

SITES RECOMMENDED FOR FURTHER RESEARCH

\begin{tabular}{|c|c|c|c|c|}
\hline Site \# & Type of Site & Location & $\begin{array}{l}\text { Archaeological } \\
\text { Potential } \\
\end{array}$ & $\begin{array}{l}\text { Description of } \\
\text { Further Research }\end{array}$ \\
\hline$E P-9$ & $\begin{array}{l}\text { Lithic work- } \\
\text { shop, possible } \\
\text { occupation }\end{array}$ & $\begin{array}{l}\text { Along west bank of West } \\
\text { Elm Creek, on long, flat, } \\
\text { clear terrace, ca. } 400 \\
\text { meters due west of hill- } \\
\text { top marked as } 1056^{\prime} \text { on } \\
\text { topographic map in west } \\
\text { central park area }\end{array}$ & $\begin{array}{l}\text { Site condition is good } \\
\text { and soil depth suggests } \\
\text { possibility of determining } \\
\text { the vertical and horizontal } \\
\text { extent of this site. }\end{array}$ & $\begin{array}{l}\text { Limited testing; } \\
50 \mathrm{~cm}^{2} \text { and } 1 \mathrm{~m}^{2} \\
\text { pits; mapping. }\end{array}$ \\
\hline$E P-10$ & $\begin{array}{l}\text { Lithic work- } \\
\text { shop, occupa- } \\
\text { tion }\end{array}$ & $\begin{array}{l}1115^{\prime} \text { hil1top ca. } 1 \mathrm{~km} \\
\text { east of U.S. Hwy } 281 \text { and } \\
1 \mathrm{~km} \text { west of West E.1m } \\
\text { Creek ca. } 400 \mathrm{~m} \text { southeast } \\
\text { of EP-11 }\end{array}$ & $\begin{array}{l}\text { Site is scattered with } \\
\text { flakes, large bifaces, } \\
\text { drills, cores and dart } \\
\text { point fragments; this } \\
\text { Archaic hilltop was inten- } \\
\text { sively occupied through- } \\
\text { out a long temporal span. }\end{array}$ & $\begin{array}{l}\text { Controlled surface } \\
\text { collection and } \\
\text { limited testing } \\
\text { where possible; } \\
\text { mapping. }\end{array}$ \\
\hline$E P-11$ & $\begin{array}{l}\text { Occupation, } \\
\text { lithic work- } \\
\text { shop }\end{array}$ & $\begin{array}{l}\text { East bank of West E1m } \\
\text { Creek, ca. } 1600 \mathrm{~m} \text { north } \\
\text { of existing road, } 800 \mathrm{~m} \\
\text { south from western windmi11 }\end{array}$ & $\begin{array}{l}\text { Six dart points were sur- } \\
\text { face collected in this } \\
\text { locality, suggesting Early } \\
\text { to Middle Archaic activities. } \\
\text { other artifacts also sug- } \\
\text { gest this was a preferred } \\
\text { occupation over many years. }\end{array}$ & $\begin{array}{l}\text { Controlled surface } \\
\text { collection and limited } \\
\text { testing where possible; } \\
\text { mapping. }\end{array}$ \\
\hline$E P-17$ & $\begin{array}{l}\text { Lithic work- } \\
\text { shop, occupa- } \\
\text { tion }\end{array}$ & $\begin{array}{l}\text { Hilltop site ca. } 500 \mathrm{~m} \\
\text { north of western windmill } \\
\text { just north of hilltop } \\
\text { marked } 1152^{\prime} \text { on } 1: 24,000 \\
\text { topographic map }\end{array}$ & $\begin{array}{l}\text { A possible midden, } 10 \times 15 \mathrm{~m} \text {, } \\
\text { may reveal much information } \\
\text { on aboriginal activities in } \\
\text { this area. }\end{array}$ & $\begin{array}{l}\text { Limited testing where } \\
\text { possible using } 50 \mathrm{~cm}^{2} \\
\text { and } 1 \mathrm{~m}^{2} \text { pits to } \\
\text { determine extent, depth } \\
\text { and content of this } \\
\text { feature; mapping. }\end{array}$ \\
\hline
\end{tabular}


Table 2 (continued)

\begin{tabular}{|c|c|c|c|c|}
\hline Site \# & Type of site & Location & $\begin{array}{l}\text { Archaeological } \\
\text { Potential }\end{array}$ & $\begin{array}{l}\text { Description of } \\
\text { Further Research }\end{array}$ \\
\hline EP-18 & $\begin{array}{l}\text { Quarry, work- } \\
\text { shop }\end{array}$ & $\begin{array}{l}\text { Just south of northwest- } \\
\text { ern boundary on west } \\
\text { slope of Classen HiTl }\end{array}$ & $\begin{array}{l}\text { A preliminary survey of } \\
\text { this large lithic scatter } \\
\text { ca. } 250 \times 300 \mathrm{~m} \text { cannot } \\
\text { determine if it is in } \\
\text { reality one large workshop } \\
\text { area or a complex of } \\
\text { smaller areas reflecting } \\
\text { distinct temporal conditions. }\end{array}$ & $\begin{array}{l}\text { Limited testing } \\
\text { where possible; con- } \\
\text { trolled surface col- } \\
\text { lection and mapping. }\end{array}$ \\
\hline$E P-21$ & $\begin{array}{l}\text { Quarry, work- } \\
\text { shop }\end{array}$ & $\begin{array}{l}\text { Hilltop and slopes of } \\
\text { hill marked as } 1173^{\prime} \text { in } \\
\text { northeast portion of } \\
\text { park area, as identified } \\
\text { on } 1: 24,000 \text { U.S.G.S. } \\
\text { topographic map }\end{array}$ & $\begin{array}{l}\text { The frequency of bifaces } \\
\text { larger than } 7 \mathrm{~cm} \text { in length } \\
\text { suggests prehistoric activ- } \\
\text { ities which could not be } \\
\text { identified in a preliminary } \\
\text { survey. }\end{array}$ & $\begin{array}{l}\text { Controlled surface } \\
\text { collection and limited } \\
\text { testing where possible; } \\
\text { mapping. }\end{array}$ \\
\hline$E P-29$ & $\begin{array}{l}\text { Occupation, } \\
\text { workshop }\end{array}$ & $\begin{array}{l}.75 \mathrm{~km} \text { west of Bulverde } \\
\text { Road and ca. } 1.75 \mathrm{~km} \\
\text { northeast of East Elm } \\
\text { Creek on } 1094^{\prime} \text { contour }\end{array}$ & $\begin{array}{l}\text { More than } 19 \text { large bifaces } \\
\text { and preforms were surface } \\
\text { collected from this local- } \\
\text { ity and this suggests inten- } \\
\text { sive prehistoric activities } \\
\text { which could not be deter- } \\
\text { mined by a preliminary } \\
\text { survey }\end{array}$ & $\begin{array}{l}\text { Controlled surface } \\
\text { collection where } \\
\text { feasible; mapping. }\end{array}$ \\
\hline
\end{tabular}


Testing activities may include a variety of methods dependent upon individual site conditions but generally include a series of hand-excavated pits, using a small shovel and trowels. Individual pits are usually not over $50 \mathrm{~cm}^{2}$ or $1 \mathrm{~m}^{2}$. Testing operations in general determine not only the depth and frequency of cultural materials but also their relationships to natural geologic stratigraphy. All materials removed from excavated areas are screened through $1 / 4-$ inch or $1 / 8$-inch hardware cloth to collect the largest possible sample of cultural materials. Soil samples are also taken for later analys is of culturally-induced changes in composition. A series of test pits throughout a site enable archaeologists, with a minimum of time and a minimum of overall site disturbance, to assess the horizontal distribution and vertical extent of prehistoric activities in a given area.

Controlled surface collection may also include a variety of methods but generally follows a systematic form of sampling (in which a grid or some other collecting system is superimposed over the site) and areas for total artifact collection are chosen to determine specific areas of aboriginal intra-site activities.

The ultimate goal of the recommended testing and intensive surface collection program will be to evaluate the sites in terms of their nomination to the National Register of Historic Places. 


\section{ACKNOWLEDGMENTS}

While conducting this survey, it was often necessary to obtain the cooperation and aid of various individuals, and their efforts and interest are gratefully acknowledged. The writers of this report are indebted to the Denton Development Corporation, and especialiy to Mr. R. A. Nelson, for his courtesy, patience, and general cooperation. T. Medlin spent long and tedious hours in survey, and V. Holloway furnished the photographs for the study. The field work was conducted under the general direction and suggestions of Dr. Thomas R. Hester, Director, Center for Archaeological Research, The University of Texas at San Antonio, and Mr. Jack Eaton, Assistant Director. 


\section{REFERENCES CITED}

Chadderdon, M. F.

1975 Notes on the Menger Collection, Site 41 BX 272, Bexar County, Texas. La Tierra 2(1):15-18.

Davis, W. B.

1974 The Mammals of Texas. Texas Parks and Wildlife Department, Bulletin 41.

Fawcett, W. B., Jr.

1972 The Prehistory of Bexar County: A Study of Previous Work in South Central Texas. Bulletin, Lower Plains Archaeological Society 2 (for 1971):23-44.

1974 A Preliminary Analysis of Prehistoric Utilization of Upland Areas Adjacent to Leon Creek, South Central Texas. La Tierra $1(1): 27-31$.

Fox, A. A. and T. R. Hester

1976 An Archaeological Survey of Coleto Creek, Victoria and Goliad Counties, Texas. Center for Archaeological Research, The University of Texas at San Antonio, Archaeological Survey Report 18.

Hester, T. R.

1975 Archaeological and Historical Resources in the San AntonioGuadalupe River Basins: A Preliminary Statement. Center for Archaeological Research. The University of Texas at San Antonio, Regional Studies 1.

1976 The Texas Archaic: A Symposium (ed.). Center for Archaeological Research. The University of Texas at San Antonio, Special Report 2:83-88.

Hester, T. R. F. A. Bass and T. C. Kelly

1975 Archaeological Survey of Portions of the Comal River Watershed, Comal County, Texas. Center for Archaeological Research. The University of Texas at San Antonio, Archaeological Survey Report 6.

Hester, T. R., R. F. Heizer and J. A. Graham

1975 Field Methods in Archaeology. Mayfield Publishing Company, Palo Alto, California.

Hester, T. R. and H. Kohnitz

1975 The Chronological Placement of "Guadalupe" Tools. La Tierra 2(2):22-25. 
Hester, T. R., F. A. Bass, Jr., A. A. Fox, T. C. Kelly, M. F. Chadderdon and E. S. Harris

1974 Archaeological Survey of Areas Proposed for Modification in the Salado Creek Watershed, Bexar County, Texas. Center for Archaeological Research. The University of Texas at San Antonio, Archaeological Survey Report 3.

Hudson, W. R., Jr., W. M. Lynn and D. Scurlock

1974 Walker Ranch, An Archeological Reconnaissance and Excavations in Northern Bexar County, Texas. Texas Historical Commission, office of the State Archeologist, Report 26.

McGraw, A. J.

1977 A Preliminary Survey and Assessment of Archaeological Resources Along Medio Creek, South Bexar County. Unpublished manuscript on file at the Center for Archaeological Research, The University of Texas at San Antonio.

Nunley, P. and T. R. Hester

1975 An Assessment of Archaeological Resources in Portions of Starr County, Texas. Center for Archaeological Research. The University of Texas at San Antonio, Archaeological Survey Report 7.

Schuetz, M. K.

1966 The Granberg Site: An Archaic Indian Habitation in Bexar County, Texas. Witte Museum Studies 1.

Scurlock, D. and W. R. Hudson

1973 An Archeological Investigation of Walker Ranch. Texas Historical Commission, Austin.

Smith H. P., Jr. and K. McDonald

1975 An Archaeological Survey of Friedrich Park, Bexar County, Texas. Center for Archaeological Research. The University of Texas at San Antonio, Archaeological Survey Report 12.

Suhm, D. D. and E. B. Jelks

1962 Handbook of Texas Archeology: Type Descriptions. Texas Archeological Society, Special Publication 1, and The Texas Memorial Museum Bulletin 4.

Taylor, F. B., R. B. Hailey and D. L. Richmond

1966 Soil Survey of Bexar County, Texas. U.S. Department of Agriculture, Soil Conservation Service, Series 1962, 12. 
Woolford, S. W.

1935 Types of Archaeological Sites in Bexar County, Texas. Witte Museum, Archaeological Bulletin 4. 